\title{
PETROGENESIS, MAJOR OXIDES AND TRACE ELEMENTS GEOCHEMISTRY OF MIGMATITE IN AJUBA, KWARA STATE, NIGERIA
}

\author{
${ }^{1}$ Adedoyin, A. D., ${ }^{1}$ Atat, A. G. \& ${ }^{* 2}$ Atat, J. G.
}

\author{
${ }^{1}$ Department of Geology and Mineral Sciences, University of Ilorin, Ilorin, Nigeria. \\ ${ }^{*}$ Department of Physics, University of Uyo, Uyo, Nigeria. \\ *Corresponding Author Phone: +2347069500697 Email: josephatat@uniuyo.edu.ng
}

\begin{abstract}
Petrogenesis, major oxides and trace elements geochemical study was carried out on migmatite in Ajuba. The study area is located on Latitudes $8^{\circ} 05^{\prime} \mathrm{N}$ and $8^{\circ} 13^{\prime} \mathrm{N}$ and Longitudes $5^{\circ} 23^{\prime} \mathrm{E}$ and $5^{\circ} 30^{\prime} \mathrm{E}$. Five rock samples were taken from the migmatite outcrops and used for petrographic and geochemical analyses. The geochemical analysis was done using X-ray Fluorescence Spectrometer technique. The dominant rock type is migmatite; gneiss and granite outcrops were also found in sparse distribution. Ptygmatic folds, which constitute the palaeosome, is the common structure observed on the migmatite rock. The petrographic analysis shows that the migmatite consists of quartz, biotite, plagioclase, hornblende and microcline. The major oxides analysis indicates $\mathrm{SiO}_{2}$ as the dominant oxide with concentration range values (70.71 wt. \% - 79.32 wt. \%) and average of 74.80 wt. \%. $\mathrm{Al}_{2} \mathrm{O}_{3}\left(14.98\right.$ wt. $\%$ - 16.44 wt. $\%$, average: 15.70 wt. $\%$ ) and $\mathrm{Fe}_{2} \mathrm{O}_{3}$ (9.10 wt. \% - 15.41 wt. \%, average: 12.39 wt. \%), $\mathrm{K}_{2} \mathrm{O}$ (6.67 wt. \% - 8.86 wt. \%, average: 7.50 wt. \%) and CaO (0.49 Wt. \% - 4.64 wt. \%. average: 2.73 wt. \%). $\mathrm{P}_{2} \mathrm{O}_{5}, \mathrm{MnO}$ and $\mathrm{TiO}_{2}$ are less than 1.0 wt. \%. The trace elements analysis indicates the concentration distributions: $\mathrm{Rb}$ (0.11-0.15 ppm, average 0.13 ppm), Co (0.04-0.17 ppm, average 0.10 ppm). Trace elements $<0.10 \mathrm{ppm}$ are $\mathrm{Zn}, \mathrm{W}, \mathrm{Ni}, \mathrm{Cu}, \mathrm{V}$ and $\mathrm{Pb}$. From the petrographic and geochemical assessment, the petrogenesis of the migmatite has silica-rich igneous parentage. Moreover, the plots of $\mathrm{SiO}_{2}-\mathrm{CaO}$ and $\mathrm{K}_{2} \mathrm{O}-\mathrm{SiO}_{2}$ placed the migmatite on the "upper boundary field of Francisian Greywacke" protolith and Shoshonite series, respectively.
\end{abstract}

Keywords: Leucosome, Major oxides, Melanosome, Migmatite, Neosome, Petrogenesis, Trace element

LICENSE: This work by Open Journals Nigeria is licensed and published under the Creative Commons Attribution License 4.0 International License, which permits unrestricted use, distribution, and reproduction in any medium, provided this article is duly cited.

COPYRIGHT: The Author(s) completely retain the copyright of this published article.

OPEN ACCESS: The Author(s) approves that this article remains permanently online in the open access (OA) model.

QA: This Article is published in line with "COPE (Committee on Publication Ethics) and PIE (Publication Integrity \& Ethics)". 


\section{INTRODUCTION}

Migmatite is a combination of metamorphic rock and igneous rock; it involves two or more different parts which are petrogenetically connected and to their protoliths (Sawyer, 2008). It is made when a gneiss, which is a metamorphic rock partially melts; and mixes with recrystallised igneous rock. They are also named diatexite. Types of migmatites include metatexites and diatexites. Metatexites have a lesser melt portion and preserved coherent pre-partial melting qualities in the palaeosome and residuum. Neosome exist dominantly in the diatexites and coherent pre-partial melting arrangements are absent (Pawley et al., 2015). The different phases of the rock are due to the transformation of some fraction that happens in the metamorphic palaeosome (Mehnert, 1971), when an originator rock is affected by considerable number of pressures and temperatures. Metamorphic rocks are aggregate of solid mass which are altered at extreme pressures and temperatures, though could form crystal again but not made through melting. Igneous rocks are solid masses that are made by cooling from entirely molten silicate material.

Migmatites are found beneath deformed metamorphic rocks that characterize the base of eroded mountain chains, frequently within Precambrian cratonic blocks (Sawyer, 2008). It is the oldest member of the Precambrian Basement complex in Nigeria (Oyawoye, 1964; Rahaman 1976; Ayodele, 2015). Migmatites are seen frequently as tightly, incoherently folded veins (ptygmatic folds). These create separations of leucosome, light-colored granitic components exsolved within melanosome (which is a dark coloured amphibole- and biotite-rich portion). Mesosome may also exist and its colour is intermediate among that of leucosome and melanosome.

According to Lyell (1837), migmatite is the penultimate part of an order of lithologic alterations. He stated that when there is a deposition of unconsolidated deposit (protolith for upcoming metamorphic rocks) and there is a rise in temperature and pressure with depth, a protolith passes through a diagenetic order from porous sedimentary rock through hard rocks and phyllites to metamorphic schists; the differentiation of the original sedimentary constituent is still possible. More so, the schists are re-formed as gneiss that folia of the remaining minerals substitute with quartzo-feldspathic portions; partial melting is still observed with sets of leucosome merge to produce separate strata in the neosome, and is seen as detectable migmatite. Goransen (1938) clarifies that the subsequent leucosome strata in stromatic migmatites hold water $\left(\mathrm{H}_{2} \mathrm{O}\right)$ and carbon (iv) oxide $\left(\mathrm{CO}_{2}\right)$ content in an irregular reaction series from the paleosome which makes the leucosome exceptionally mobile. Holmquist (1916) stated that metamorphic rocks are converted into granulite; the procedure is termed anataxis. Imasuen and Onyeobi (2014) have conducted petrographic analyses of the rock samples which shows migmatites consist of quartz, feldspar (plagioclase, microcline and orthoclase) and also biotite.

Every rock is made due to different chemical, physical and biological conditions which lead to the creation of an extensive and distinct set of minerals and therefore result in submissions in various fields. Rocks are durable, soft, penetrable and impermeable; they are of several sizes and shapes. Migmatites have an attractive look, frequently being noticeable with irregular small areas of distinct shades fluctuating from nearly white to dark grey, and are extensively used as building stones, occasionally being refined for ornament. Migmatite in the construction industry comprises dimension stones and, road aggregate. It uses also include countertops, floor design, as facing stone, curbing, as artifacts, cemetery indicators, jewelry, tombstones, manufacturing of object stopping breeze from blowing 
papers and bookends. This study aims to determine the petrogenesis of migmatite from petrographic and geochemical analyses.

\section{LOCATION, CLIMATE AND GEOLOGY OF THE STUDY AREA}

Ajuba is one of the villages in Osi, Kwara State of Nigeria at about $4000 \mathrm{~m}$ west of Osi on Latitude $8^{\circ} 05^{\prime} \mathrm{N}$ and $8^{\circ} 13^{\prime} \mathrm{N}$ and Longitude $5^{\circ} 23^{\prime} \mathrm{E}$ and $5^{\circ} 30^{\prime} \mathrm{E}$. It covers an area of $9 \mathrm{~km}^{2}$ (Figure 1). One of the major villages in Osi is Ajuba settlement and it is situated within two rock suites, namely: Osi migmatite-gneiss complex to the west and Egbe schist belt to the east (Bamigboye \& Adekeye, 2011).

The study area has dry and rainy seasons as the two alternating climatic conditions. The annual rainfall is between $1270 \mathrm{~mm}$ and $1524 \mathrm{~mm}$, spread over the month of April to October. The maximum rainfall is usually experienced around June/July. The monthly temperature is maximum in March at about $30^{\circ} \mathrm{C}$ and minimum (lowest) in August at about $25^{\circ} \mathrm{C}$ (Olasehinde, 1999). Conversely, the dry season starts in November and ends in March.

The geology of Nigeria involves older and younger meta-sediments, Older and Younger Granites, and volcanic intrusives which are overlain by younger sedimentary basins of Illumeden, Chad, Dahomey, Benue, Bida, and Niger-Delta (Rahaman, 1976). The most dominant rocks include gneiss, granite, gabbro, migmatite, amphibolite and pegmatite. The granites are porphyritic and occur as boulders beside the river channel. Enormous outcrop of porphyritic granite is sited about $8 \times 10^{2} \mathrm{~m}$ south of the area. A typical feature of the Basement Complex tectonics is the widespread existence of fractures (Akinrinmade et al., 2013). The varieties of surface essential features such as foliations, folds, faults, joints, fractures and fissures are noted. The presence of joints, faults and fractures in the subsurface are signs of a healthier and recommended aquifer (Olasehinde, 1999). It was observed that the rivers are constantly flooded by water at the peak of the rainy season; the flow rate drops to the average of about $2.7 \mathrm{~ms}^{-1}$ in the dry season and maintains the average of about $7.4 \mathrm{~ms}^{-1}$ during the wet season (Akinrinmade et al., 2013).

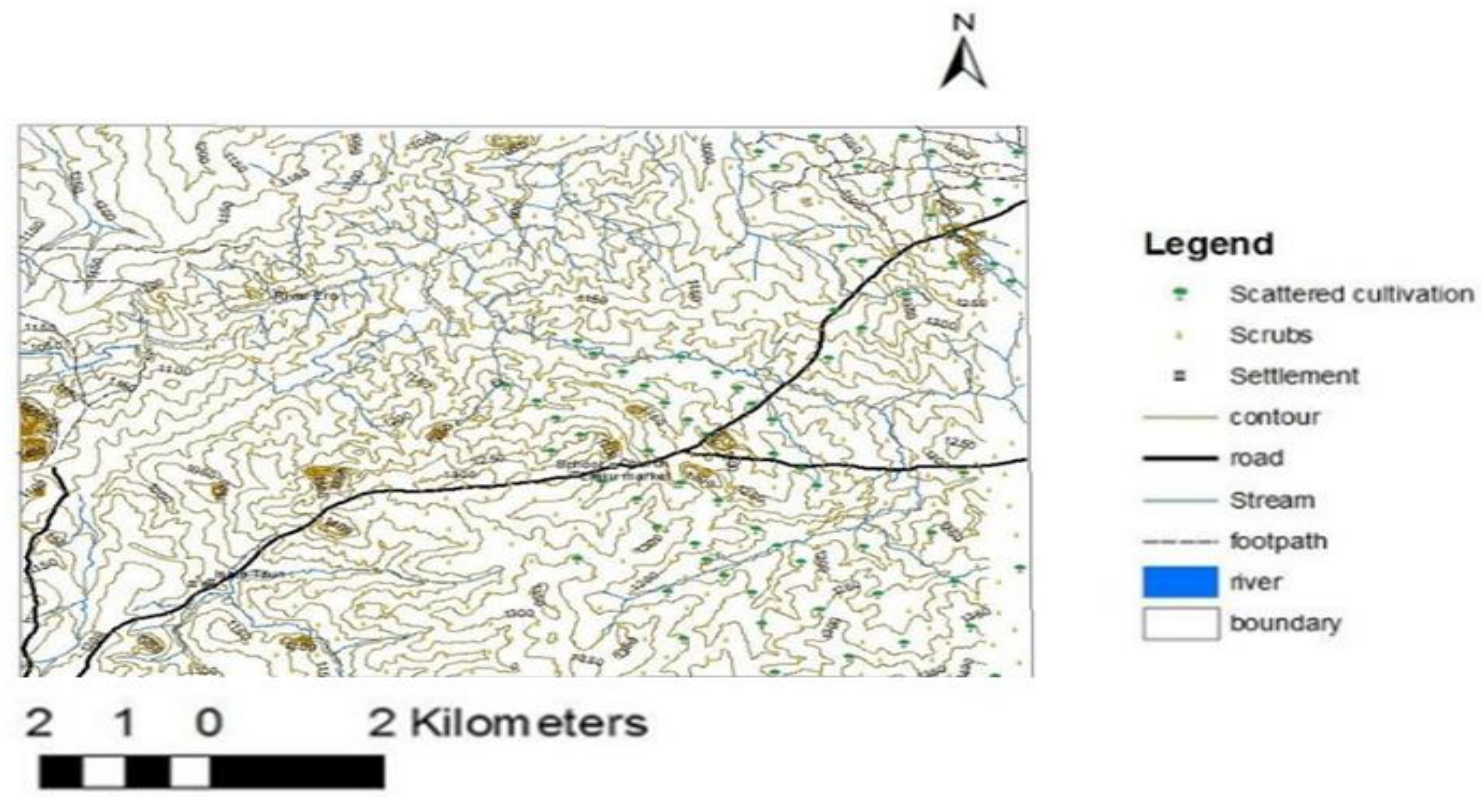

Figure 1: Topographic map of Osi

Source: Akinrinmade et al. (2013). 


\section{GENESIS OF MIGMATITE}

A metamorphic rock is a rock that has been transformed inside the Earth unto a new type of rock in terms of its body (metasomatic), mineralogic and geochemical (petrologic) content. The source rock from which a metamorphic rock came is called the protolith. Metamorphism can be triggered by burial, tectonic stress, heating by magma or modification by intruding fluids. Protolith of a migmatite may suffer partial melting to become neosome. The unaltered protolith in migmatite is called palaeosome and it usually has conspicuous features such as foliations, folds and layering. Some rocks in a palaeosome are resistant to partial melting or microstructural alteration and they are called resisters (for example, quartzites, calc-silicates, and metamafic rocks). Neosome has two sections, namely: melt and magma. The melt is a silicate liquid without crystals, while magma is a silicate liquid that comprises crystals. The crystals may have either crystallized from the melt (which is liquidus phases) or they are the solid product of the melt response (also called peritectic products). Magmas are non-Newtonian fluids. Newtonian fluids are fluids that have a linear comparative connection among differential stress and shear strain (that is, the viscosity of the fluid will not be changed irrespective of any external stresses). Non-Newtonian ones are categorized by a non-linear relationship between the shear stress and the shear strain. As a consequence, the viscosity will vary and become thinner or thicker once external stresses are applied. The neosome comprises the solid (which are residuum and melanosome) and the liquid (which is leucosome) components of the melt creating metamorphic response (Sawyer, 2008; Pawley et al., 2013).

The leucosome results from segregated partial melt and it may comprise microstructures that show crystallisation from a melt or magma. Leucosomes may be in-situ (if a darker selvedge of mafic minerals and other minerals like garnet or cordierite are present which in turn characterizes the solid products of the melt reaction) or segregated and migrated from their source. In-situ leucosome results from the crystallisation of an anatectic melt or part of a melt, which has segregated from the residuum but has stayed at the site where the melt was formed. In-source, leucosome results from anatectic melt, which has moved away from the place where it was formed but is still around the boundaries of its source layer. The outcome of crystallisation of a felsic portion that has migrated from its source area entirely into non-metamorphosed rocks is granite dyke, sill, and pluton. Partial melting or anataxis yields metatexite and diatexite with mineralogical and chemical arrangements (Afolabi et al., 2019).

\section{MATERIALS AND METHOD}

The field materials used are topographic map, hammer, chisel, compass clinometers, sample bag, marker, safety gear, footwear, pencil, pen and notebook. The laboratory materials used are, petrographic microscope, rock cutting machine, X-ray Fluorescence spectrometer, jaw crusher, pulveriser, etc.

The fieldwork involved geological mapping on a scale of 1:12,500 resulting in the geological map (Figure 2). The laboratory work involved sample preparation, petrographic study and geochemical analysis.

The petrographic study was undertaken with the aid of petrographic microscope at the Microscopic Laboratory, Department of Geology and Mineral Sciences, University of Ilorin, Nigeria. Five rock samples were made into several thin sections and subsequently polished using carborundum powder to obtain slides with the required thickness and a 
perfectly smooth surface. Fresh rock samples were collected for hand specimen examination. Preliminary observation and identification of each constituent mineral were carried out.

Five samples of migmatite were noted and collected for geochemical analysis. About $1 \mathrm{~kg}$ of each sample was broken into pieces with a hammer and crushed into smaller pieces with a jaw crusher. The samples were thereafter pulverised in a disc mill for about two minutes and shipped for major oxides and trace elements analyses at Jiangsu Skyray Instrument Company Limited, Ibadan, Nigeria using X-ray Fluorescence Spectrometer technique. Mineral identification was carried out at the Microscopic Laboratory, Department of Geology and Mineral Sciences, University of Ilorin, Nigeria.

\section{RESULTS AND DISCUSSION}

\section{RESULTS}

The result of field studies reveals that the rocks in the study area are majorly migmatite, gneiss and granites [with migmatite about $60 \%$ of the total visible rocks] (Figure 2). Figure 3 presents the field photograph of migmatite with ptygmatic folds in Ajuba town. The photomicrograph of possible migmatite minerals is contained in Figure 4. The amounts of major oxides and trace elements detected are presented in Tables 1 and 2 [with their average results in Table 3]. The most abundant major oxides and trace elements are presented in Figures 5 and 8, respectively. Figure 9 presents the major oxides for sample locations.

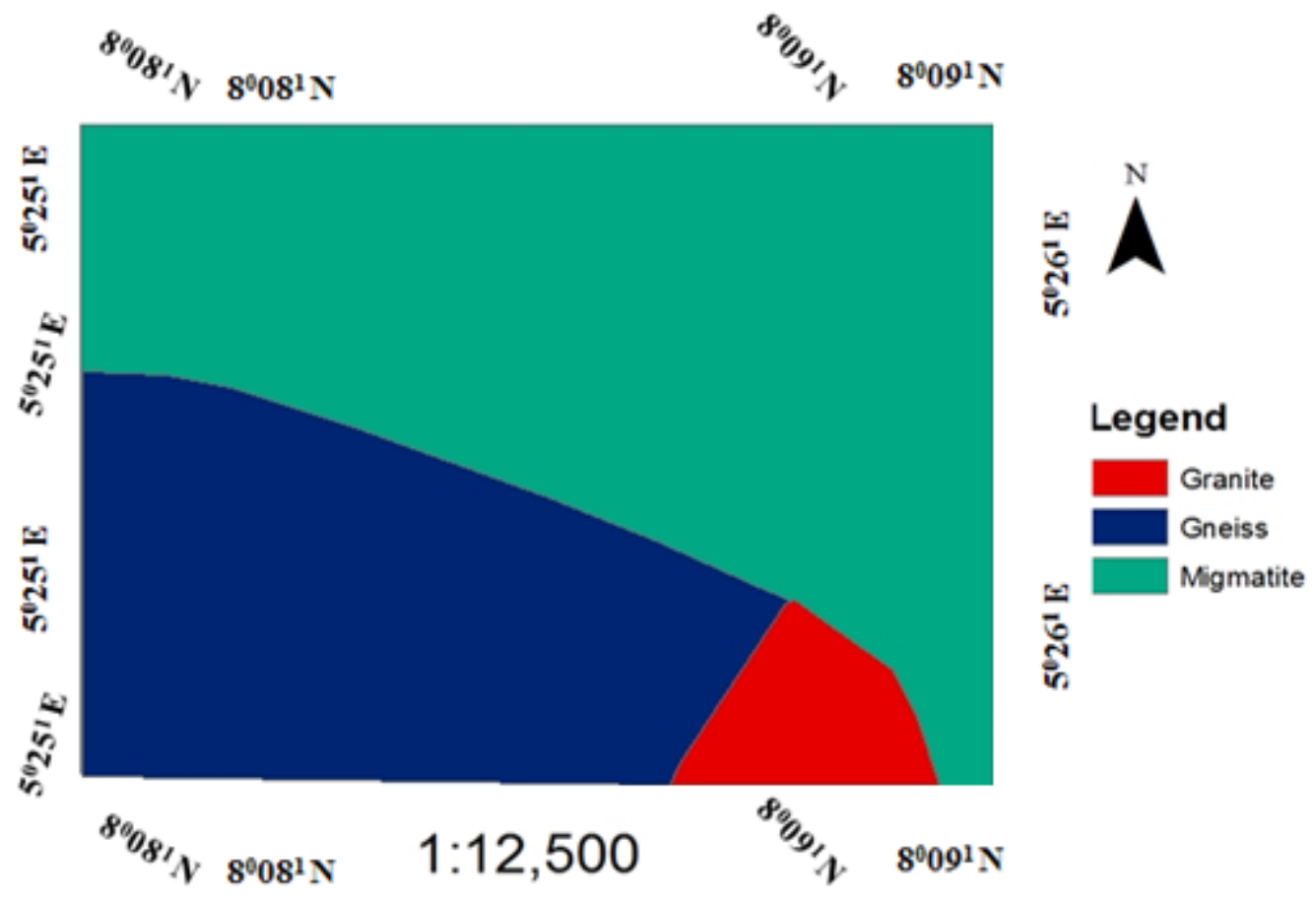

Figure 2: Rock Map of the Area 


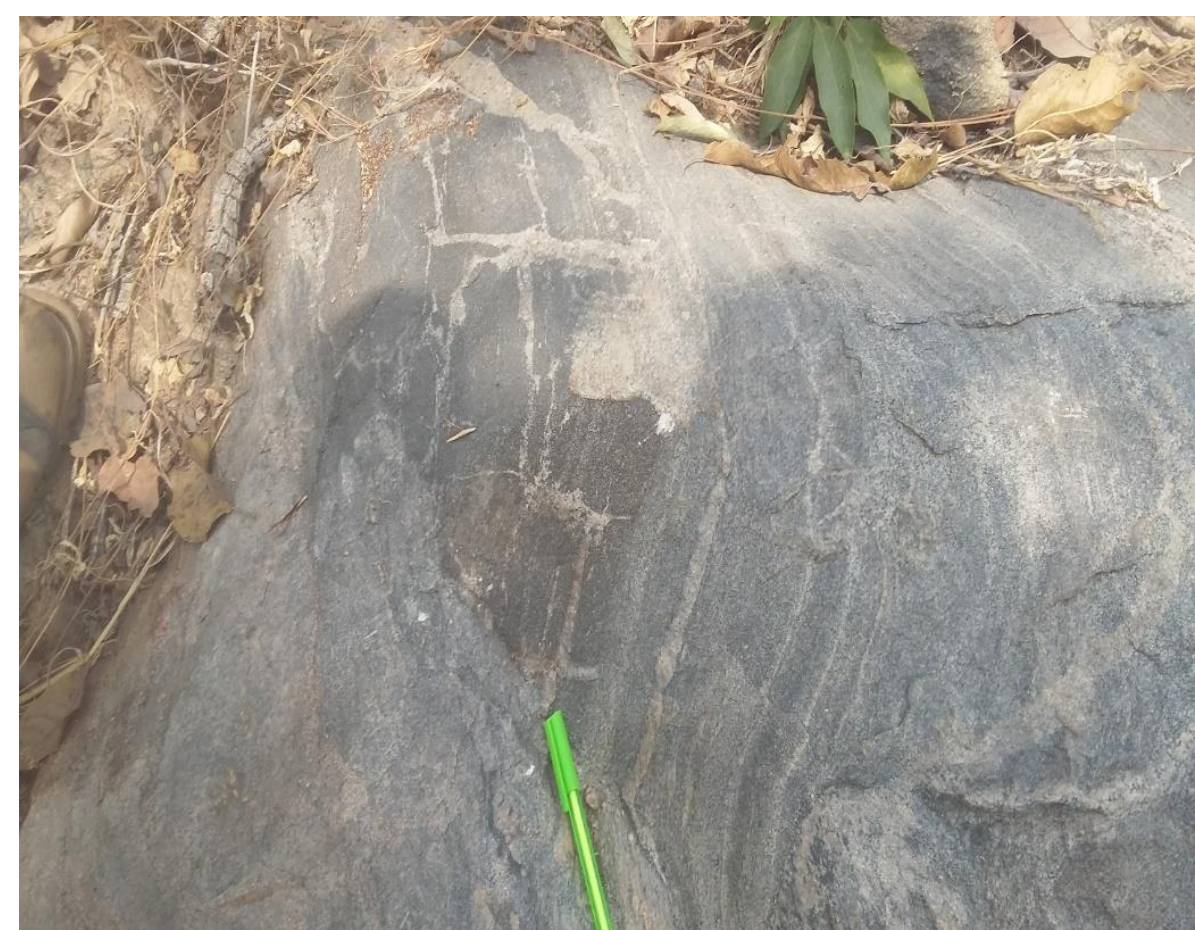

Figure 3: Field photograph of migmatite with ptygmatic folds in Ajuba town.

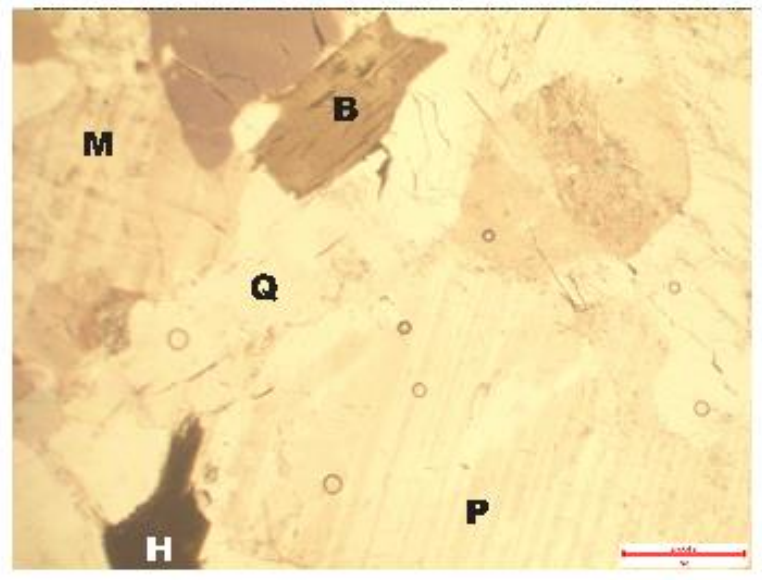

a

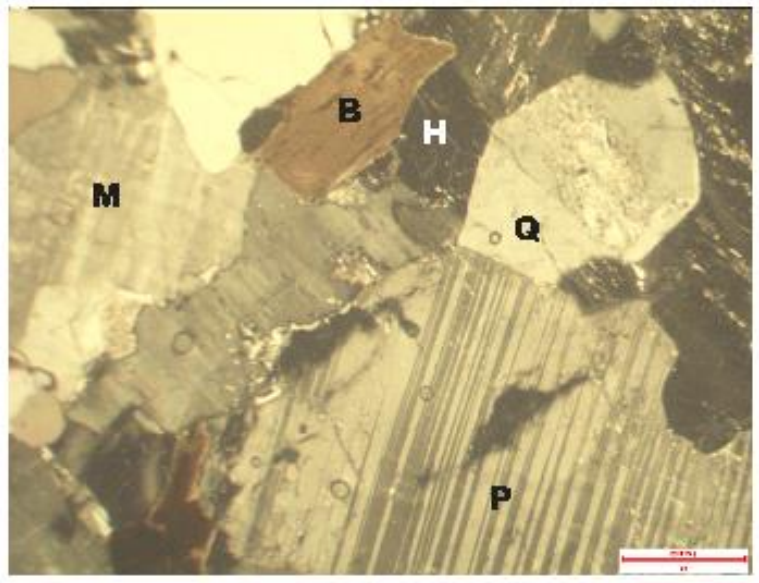

b

Figure 4: Photomicrograph of migmatite under (a) plane polarised light $(\mathrm{b})$ crossed polarised light; $\mathrm{Q}=\mathrm{Quartz}, \mathrm{B}=$ Biotite, $\mathrm{P}=$ Plagioclase, $\mathrm{H}=$ Hornblende, $\mathrm{M}=$ Microcline. 
Table 1: Amounts of available major oxides

\begin{tabular}{lllllllll}
\hline Locations & \multicolumn{2}{l}{ Major oxides } & & & & & \\
& $\mathbf{S i O}_{2}$ & $\mathbf{A l}_{2} \mathbf{O}_{3}$ & $\mathbf{F e}_{2} \mathbf{O}_{3}$ & $\mathbf{K}_{2} \mathbf{O}$ & $\mathbf{C a O}$ & $\mathbf{P}_{2} \mathbf{O}_{5}$ & $\mathbf{M n O}$ & $\mathbf{T i O}_{2}$ \\
\hline AJ1A & 73.660 & 15.708 & 15.414 & 6.666 & 4.643 & 0.505 & 0.144 & 0.190 \\
AJ1B & 79.316 & 15.347 & 14.708 & 7.026 & 2.514 & 0.464 & 0.121 & 0.257 \\
AJ8 & 78.990 & 16.439 & 9.094 & 7.657 & 1.944 & 0.470 & 0.077 & 0.111 \\
AJ9 & 71.296 & 14.984 & 11.147 & 8.860 & 0.488 & 0.463 & 1.291 & 0.201 \\
AJ10 & 70.713 & 15.976 & 11.585 & 7.268 & 4.063 & 0.490 & 0.109 & 0.128 \\
Total & 373.975 & 78.454 & 61.948 & 37.477 & 13.652 & 2.392 & 1.742 & 0.887 \\
AVE & 74.795 & 15.6908 & 12.3896 & 7.4954 & 2.7304 & 0.4784 & 0.3484 & 0.1774 \\
\hline
\end{tabular}

Table 2: The trace elements analysis results

\begin{tabular}{llllll}
\hline Trace Elements & $\begin{array}{l}\text { Locations } \\
\text { AJ1A }\end{array}$ & AJ1B & AJ8 & AJ9 & AJ10 \\
\hline $\mathrm{Rb}$ & 0.1125 & 0.1219 & 0.1434 & 0.1529 & 0.1329 \\
$\mathrm{Co}$ & 0.1003 & 0.1716 & 0.0376 & 0.0614 & 0.1413 \\
$\mathrm{Zn}$ & 0.0942 & 0.0880 & 0.0797 & 0.0766 & 0.0838 \\
$\mathrm{~W}$ & 0.0853 & 0.0514 & 0.0439 & 0.0651 & 0.0645 \\
$\mathrm{Ni}$ & 0.0407 & 0.0377 & 0.0459 & 0.0418 & 0.0391 \\
$\mathrm{Cu}$ & 0.0313 & 0.0292 & 0.0336 & 0.0280 & 0.0325 \\
$\mathrm{Au}$ & 0.0000 & 0.0000 & 0.0000 & 0.0000 & 0.0934 \\
$\mathrm{~V}$ & 0.0214 & 0.0176 & 0.0136 & 0.0189 & 0.0149 \\
$\mathrm{Cr}$ & 0.0124 & 0.0099 & 0.0074 & 0.0056 & 0.0087 \\
$\mathrm{~Pb}$ & 0.0035 & 0.0120 & 0.0000 & 0.0078 & 0.0019 \\
$\mathrm{TOTAL}$ & 0.8225 & 0.8682 & 0.7232 & 0.8143 & 0.9020 \\
\hline
\end{tabular}

Table 3: Average amount of major oxides (in percentage) and trace elements

\begin{tabular}{llll}
\hline Major oxides & Average major oxides & Trace elements & $\begin{array}{l}\text { Average amount of trace } \\
\text { elements }\end{array}$ \\
\hline $\mathrm{SiO}_{2}$ & & $\mathrm{Rb}$ & 0.13272 \\
$\mathrm{Al}_{2} \mathrm{O}_{3}$ & 74.7950 & $\mathrm{Co}$ & 0.10244 \\
$\mathrm{Fe}_{2} \mathrm{O}_{3}$ & 15.6908 & $\mathrm{Zn}$ & 0.08446 \\
$\mathrm{~K}_{2} \mathrm{O}$ & 12.3896 & $\mathrm{~W}$ & 0.06204 \\
$\mathrm{CaO}$ & 7.4954 & $\mathrm{Ni}$ & 0.04104 \\
$\mathrm{P}_{2} \mathrm{O}_{5}$ & 2.7304 & $\mathrm{Cu}$ & 0.03092 \\
$\mathrm{MnO}$ & 0.4784 & $\mathrm{Au}$ & 0.01868 \\
$\mathrm{TiO}_{2}$ & 0.3484 & $\mathrm{~V}$ & 0.01728 \\
& 0.1774 & $\mathrm{Cr}$ & 0.0088 \\
& & $\mathrm{~Pb}$ & 0.00504 \\
\hline
\end{tabular}




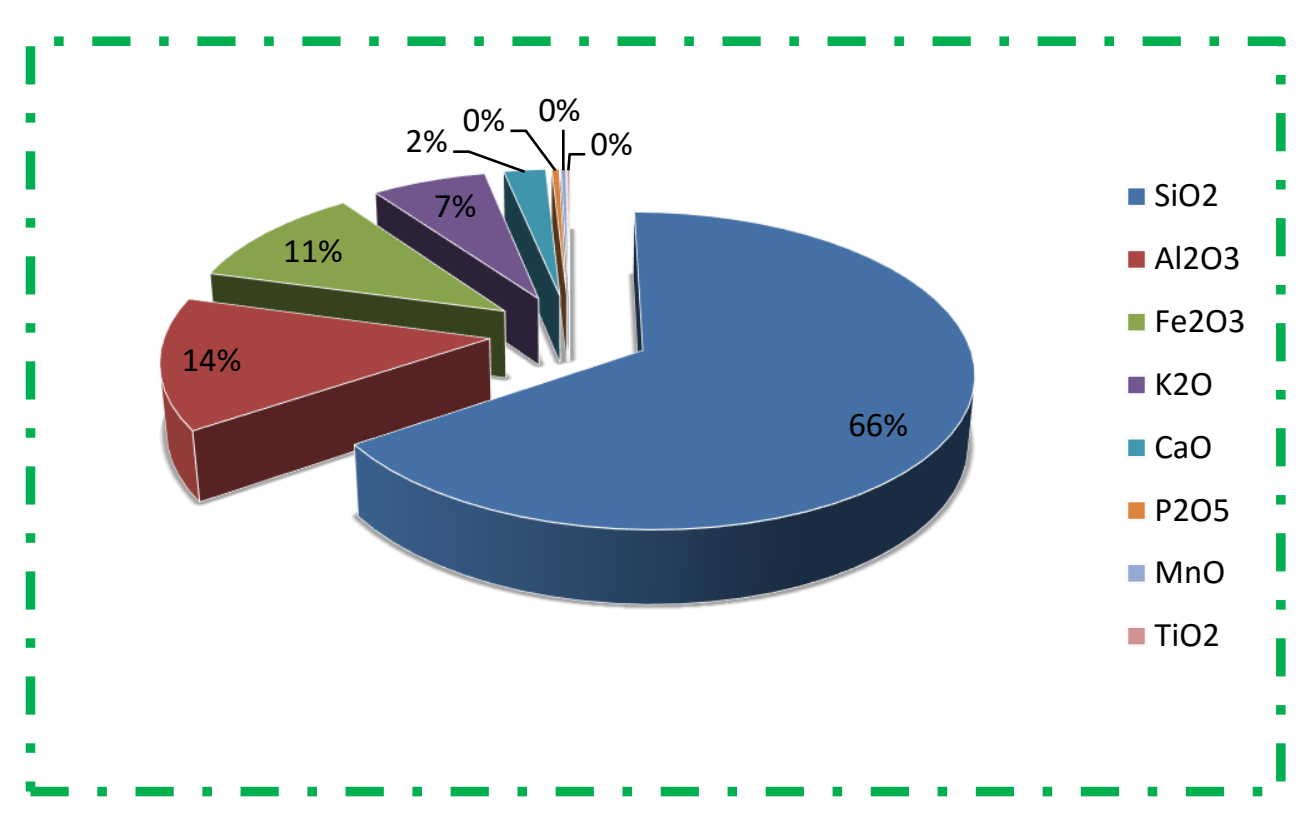

Figure 5: The pictorial representation of major oxide

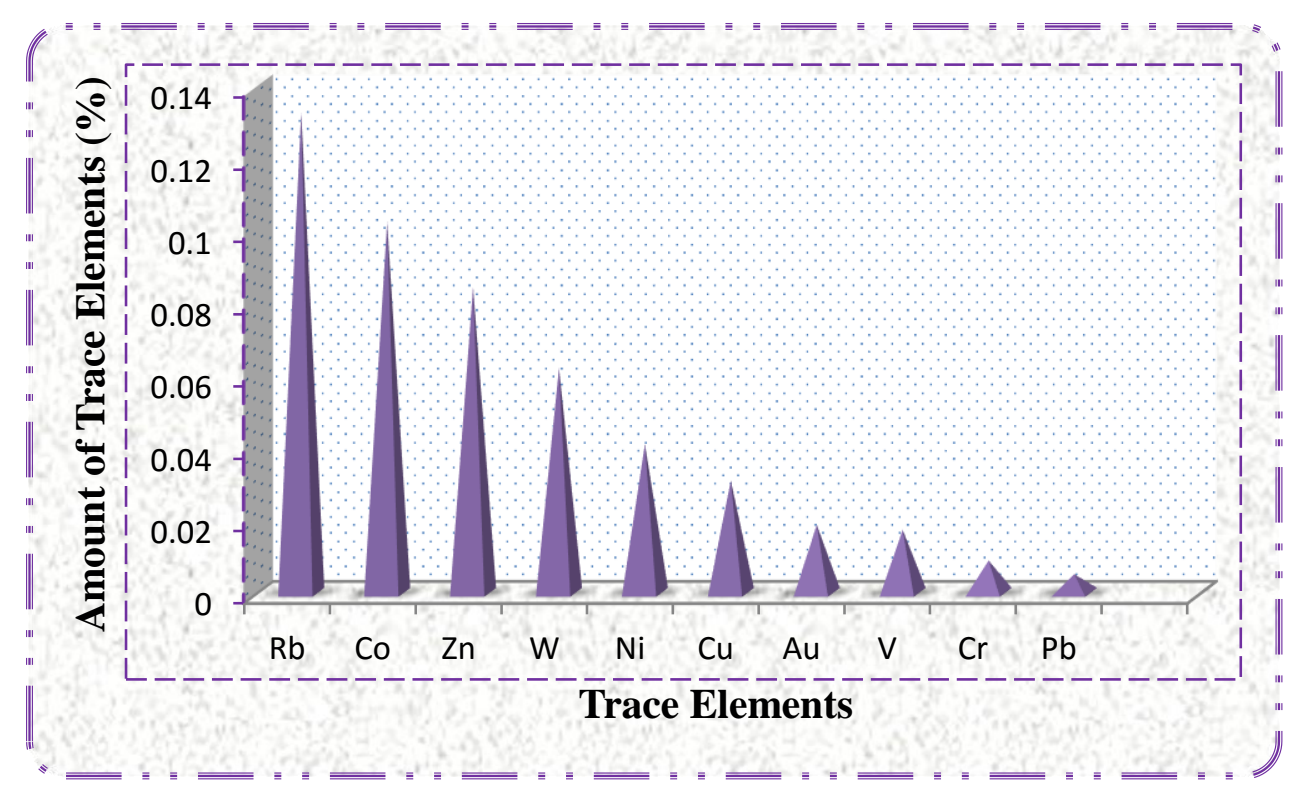

Figure 6: Trace elements in order of decreasing amount 


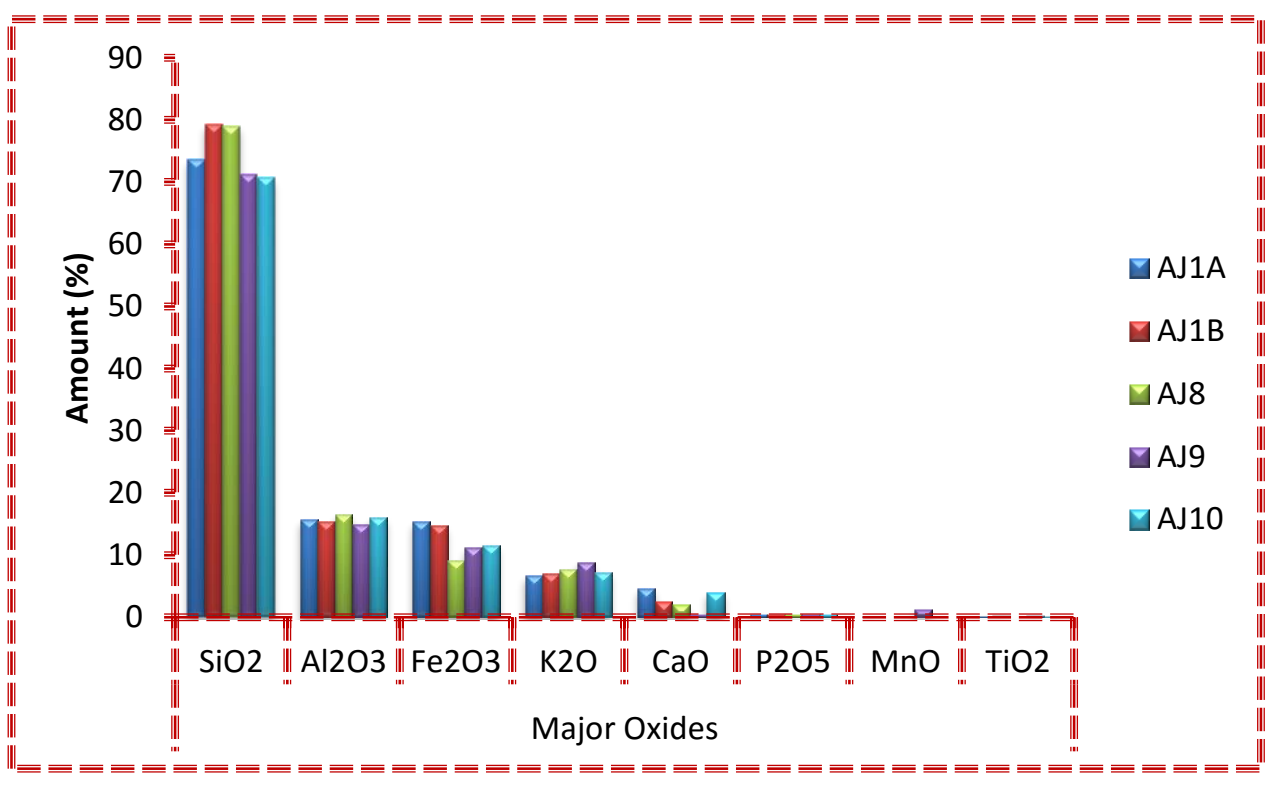

Figure 7: Histogram of concentration of major oxides with respect to their sample locations

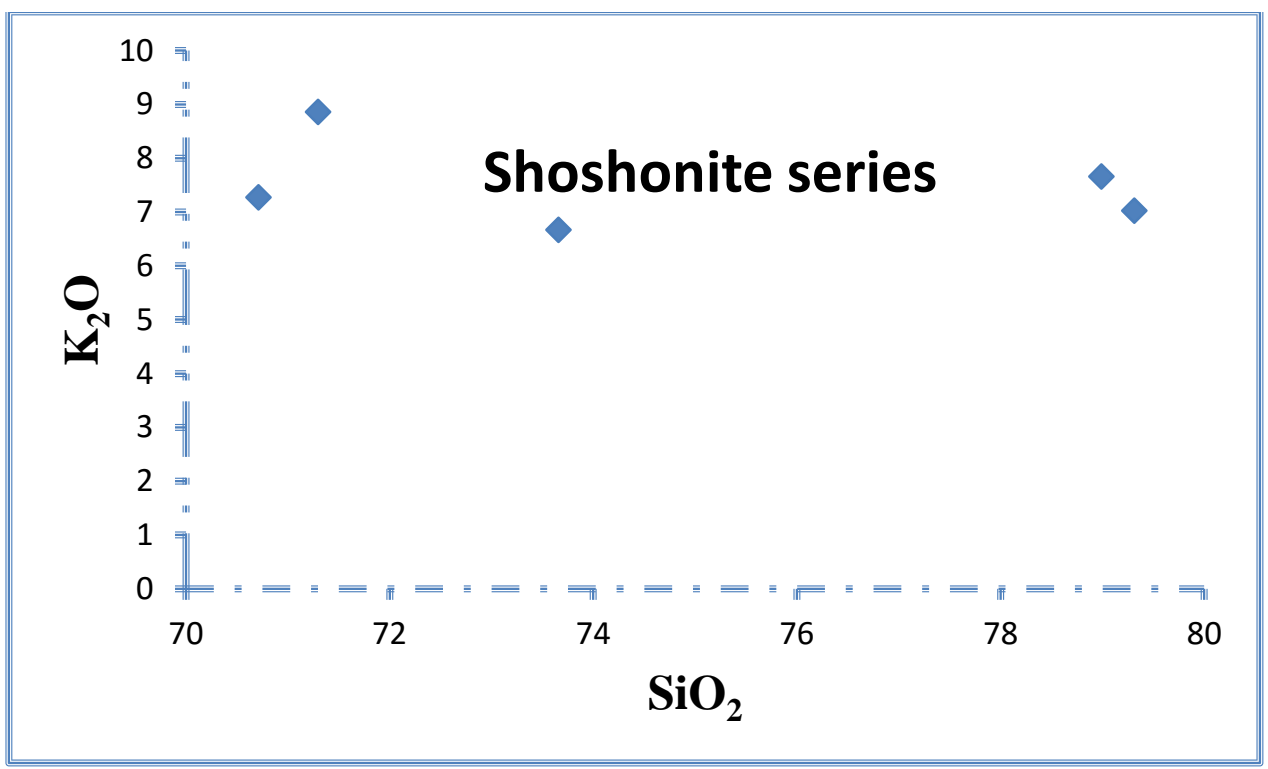

Figure 8: $\mathrm{K}_{2} \mathrm{O}-\mathrm{SiO}_{2}$ plot for series classification 


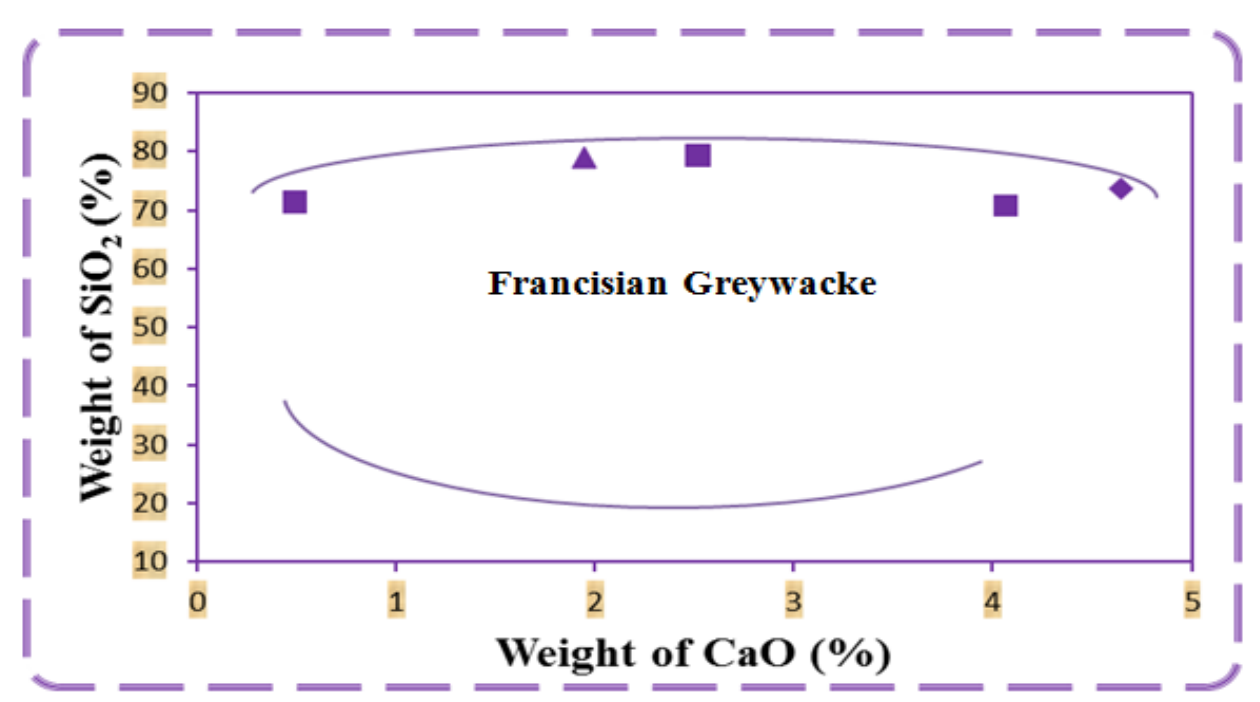

Figure 9: $\mathrm{SiO}_{2}-\mathrm{CaO}$ plot (field of Francisian Greywacke after Brown et al., 1979)

\section{DISCUSSION}

The migmatite outcrops in the study area are medium-grained in texture and they occur in the southwestern and southeastern parts of the study area. Field evidence indicates that they were partially migmatised by the intrusion of acidic magma resulting in distinct felsic and mafic bands. Migmatite is very useful as dimension stones and aggregates in road, bridges and dam's construction. This outcrop covers about $60 \%$ of the study area (Figure 2). Most of the outcrops are very visible along the river channels as weathered material. The common structure observed in this rock is ptygmatic folds which constitute the palaeosome (Figure 3).

In hand specimen, migmatites investigated are of alternating ensembles of light and dark coloured minerals (leucosome and melanosome minerals). The dark coloured are biotite and hornblende, while the light coloured are quartz and feldspar (Figure 4). Thin section studies revealed that the melanosome consists of hornblende and biotite, while the leucosome consists of plagioclase, quartz and microcline. The partial melting was possible due to temperature and pressure greater than $650^{\circ} \mathrm{C}$ and $34 \mathrm{Mpa}$, respectively.

Tables 1 and 2 accounts for the percentage weight of major oxides and the type of trace element detected, respectively. The average of major oxides was computed as seen in Table 3 to give an account of the mean percentage of these oxides in Ajuba. It also includes those of trace elements. Major oxides geochemical analysis indicates silicon (iv) oxide $\left(\mathrm{SiO}_{2}\right)$ as the dominant major oxide in the area with a concentration range values $(70.71 \mathrm{wt} . \%-79.32 \mathrm{wt}$. $\%)$ and an average of 74.80 wt. \%. $\mathrm{Al}_{2} \mathrm{O}_{3}\left(14.98\right.$ wt. $\%$ - 16.44 wt. \%, average: 15.70 wt. \%) and $\mathrm{Fe}_{2} \mathrm{O}_{3}(9.10$ wt. \% 15.41 wt. \%, average: 12.39 wt. \%), $\mathrm{K}_{2} \mathrm{O}$ (6.67 wt. \% - 8.86 wt. \%, average: 7.50 wt. \%) and $\mathrm{CaO}(0.49$ Wt. \% - 4.64 wt. \%. average: 2.73 wt. \%). $\mathrm{P}_{2} \mathrm{O}_{5}, \mathrm{MnO}$ and $\mathrm{TiO}_{2}$ are less than 1.0 wt. \%. The trace elements geochemical analysis indicates the following concentration distributions: $\mathrm{Rb}(0.11-0.15 \mathrm{ppm}$, average $0.13 \mathrm{ppm})$, Co (0.04-0.17 ppm, average $0.10 \mathrm{ppm}$ ). Trace elements with less than $0.10 \mathrm{ppm}$ in the area are $\mathrm{Zn}, \mathrm{W}, \mathrm{Ni}, \mathrm{Cu}, \mathrm{V}$ and $\mathrm{Pb}$. From the petrographic and geochemical assessment, the petrogenesis of the migmatite has been inferred to have silica-rich igneous parentage. Moreover, the plots of $\mathrm{SiO}_{2}-\mathrm{CaO}$ (Figure 9) and $\mathrm{K}_{2} \mathrm{O}-\mathrm{SiO}_{2}$ placed the migmatite on the "upper 
boundary field of Francisian Greywacke" protolith and Shoshonite series, respectively. $\mathrm{K}_{2} \mathrm{O}-\mathrm{SiO}_{2}$ plot in Figure 8 was used in line with Peccerilo \& Taylor (1976), Brako et al. (2020) \& Morrison (1980)] to classify the migmatite of the study area into shoshonite series. Besides, shoshonite series, other possible classification using the $\mathrm{K}_{2} \mathrm{O}_{-} \mathrm{SiO} \mathrm{O}_{2}$ plot for migmatite of the study area are tholeiite, cal-alkaline, high- $\mathrm{K}$ calc-alkaline series. $\mathrm{K}_{2} \mathrm{O}-\mathrm{SiO}_{2}$ plot $($ Figure 8 ). corroborated that the migmatite rock is mostly of igneous intrusion (which is a group of saturated in silica, low iron enrichment, low $\mathrm{TiO}_{2}$ as in the case of this research [it is the least amount], high but variable $\mathrm{Al}_{2} \mathrm{O}_{3}$ approximated to 16 wt. $\%$.

\section{CONCLUSION}

Migmatite is the major rock type within the mapped area: Ajuba with $60 \%$ abundance when compared to other rocks noted during the survey. The common structure observed in this rock is ptygmatic folds which make up the palaeosome. Migmatite outcrops investigated are made up of alternating bands of light and dark coloured minerals (leucosome and melanosome minerals). Silicon (iv) oxide $\left(\mathrm{SiO}_{2}\right)$ is the most abundant oxide in the area with an average of 74.80 wt. \%) and concentration range values of $70.71 \mathrm{wt} . \%-79.32 \mathrm{wt} \%$. Rb is the most abundant trace element in the study area with concentration range value $(0.11-0.15 \mathrm{ppm})$ and an average value of $0.13 \mathrm{ppm}$. It is followed by Co (0.04-0.17 ppm, average $0.10 \mathrm{ppm}$ ). Trace elements with less than $0.10 \mathrm{ppm}$ in the area are $\mathrm{Zn}, \mathrm{W}, \mathrm{Ni}, \mathrm{Cu}, \mathrm{V}$ and $\mathrm{Pb}$. The petrographic and geochemical results established the petrogenesis of the migmatite to be of silica-rich igneous parentage. $\mathrm{K}_{2} \mathrm{O}-\mathrm{SiO}_{2}$ plot indicates that the migmatite rock is mostly of igneous intrusion and classified the mapped region into shoshonite series. Lastly, the plot of $\mathrm{SiO}_{2}-\mathrm{CaO}$ defined the area covered be located "at the upper boundary of the field of Francisian Greywacke".

\section{CONFLICT-OF-INTEREST DISCLOSURE}

No conflict of Interest. 


\section{REFERENCES}

Afolabi, A. O., Lawal, R. O., Ogunmiyide, E. O. \& Adeosun, K. (2019). Geochemical Characterisation of Anatexite within High Grade Migmatite Complex Terrain from Ogbomoso, Southwest of the Nigeria Precambrian Basement Complex. American Scientific Research Journal for Engineering, Technology and Sciences (ASRJETS), 61(1): 224-246.

Akinrinmade, A. O., Ogunsanwo, O., \& Ige, O. O. (2013). Geophysical and Geotechnical Investigation of River Ero, Ajuba, Southwestern Nigeria for Dam Development. International Journal of Science and Technology (IJST), 2(7): 518-528.

Ayodele, O. S. (2015). The Geology, Geochemistry and Petrogenetic Studies of the Precambrian Basement Rocks around Iworoko, Are and Afao Area, Southern Nigeria. Journal of Geology and Geophysics, 4(4): 1-7.

Bamigboye, O. S. \& Adekeye, J. I. D. (2011). Stream Sediment Survey of Eruku and its Environs, Central Nigeria: Implication for Exploration. International Journal of Research and Reviews in Applied Sciences, 7(2): 160-171.

Brako, B. A., Foli, G., Adomako-Ansah, K., Aikins, D., Dery, S. \& Gawu, S. K. Y. (2020). Petrography and Geochemistry of some Paleoproterozoic Granitoids at the North-Eastern Margin of the Kumasi Basin in Ghana. Earth Sciences Malaysia, 4(2): 87-95.

Brown, E. H., Babcock, R. S., Clark, M. D. \& Livingstone, D. E. (1979). Geology of the Older Precambian Rocks of the Grand Canyon, I, Petrology and Structure of the Vishu Complex. Precambrian Research, 8: 219-241.

Goransen, R. (1938). Silicate - Water Systems: Phase Equilibria in the $\mathrm{NaAlSi}_{3} \mathrm{O}_{8}-\mathrm{H}_{2} \mathrm{O}$ and $\mathrm{KALSi}_{3} \mathrm{O}_{8}-\mathrm{H}_{2} \mathrm{O} \mathrm{Systems}$ at High Temperatures and Pressures. American Journal of Science, 35A: 71-91.

Holmquist, P. (1916). Swedish Archean Structures and their Meaning. Bulletin of the Geological Institute Upsala. 15: 125-148.

Imasuen, O. I. \& Onyeobi, T. U. S. (2014). Geochemical Characterization and Petrogenetic Evaluation of Migmatites around Ganaja, Kogi State, Nigeria. Advances in Applied Science Research, 5(3): 152-162.

Lyell, C. (1837). Principles of Geology. London: John Murray.

Mehnert, K. R. (1971). Migmatites and the Origin of Granitic Rocks (Developments in Petrology). Amsterdam: Elsevier Publishing Company.

Morrison, G. W. (1980). Characteristics and Tectonic Setting of the Shoshonite Rock Association. Lithos, 13: $97-108$.

Olasehinde, P. I. (1999). Characteristics of Rain, Groundwater and Surface Water in the area of Ilorin, Kwara State, Nigeria. Zb1. Geol. Palaont Teil 1(3-4): 149-158.

Oyawoye, M. O. (1964). The Geology of the Nigerian Basement Complex. Journal of Nigerian Mining (Geology and Metallurgical Society), 1(2): 87-102.

Pawley, W., Reid, A., Dutch, R. \& Preiss, W. (2015). Demystifying Migmatites: Introduction for Field-Based Geologist. Applied Earth Science, 124(3): 147-174. 
Pawley, M. J., Reid, A. J., Dutch, R. A. \& Preiss, W. V. (2013). A User's Guide to Migmatites. Report Book. South Australia, Adelaide: Department of Manufacturing, Innovation, Trade, Resources and Energy.

Peccerilo, A. \& Taylor, S. R. (1976). Geochemistry of Eocene Cal-Alkaline Volcanic Rocks from Kastamonu Area, Northern Turkey. Contributions to Mineralogy and Petrology, 58: 63-81.

Rahaman, M. A. (1976). Review of the Basement Geology of Southwestern Nigeria. In: C. A. Kogbe, (ed): Geology of Nigeria. (pp. 41 -58). Lagos: Elizabethan Publication Company.

Sawyer, E. W. (2008). Atlas of Migmatites. Ottawa, Ontario, Canada: Canadian Mineralogist Special Publication 9, NRC Research Press. 